
et al., 2012). One reputable study suggests that the total data volume in organizations doubles every 18 months (Forrester Research, 2010). In terms of velocity, big data can be used for real-time decision making. Moreover, the availability of more and faster data means that its veracity becomes harder to determine.

Such changes in data characteristics call for corresponding changes in information processing and decision making. As data become cheaper, the complements to data become more valuable (McAfee \& Brynjolfsson, 2012). Accordingly, new complementary analytics have evolved that ultimately establish new degrees of information visibility. Those analytics are based on new parallel technologies, such as MapReduce and Hadoop, that process large amounts of data at low cost. Further, big data analytics exploit new technologies, like inmemory and columnar stores, that analyze huge data sets in real-time. Such developments mark the beginning of big data use in day-to-day operations. Previously, access to information-centric systems like data warehouses was reserved for strategic decision support, while process-centric systems, such as Enterprise Resource Planning (ERP), support daily operations. System separation was introduced in the 1990s to allow the analysis of large datasets with good response performance. Recently, however, big data-related technologies like in-memory databases make system separation obsolete as "...transactional and decisionrelated data is managed in an integrative manner" (Loos et al., 2011: 394). Additionally, workers at the operational level have access to virtually unlimited external information via the Internet. Therefore, information visibility at the operational level increased significantly with the onset of the big data era. Organizations which provide analytical information to their operational decision makers perform better than those without analytical information provisioning at the operational level (Lock, 2010).

Digital companies such as Amazon have disrupted industries with new data-driven business models. Big data companies will also change traditional business as they can make more accurate predictions, better decisions, and precise interventions instead of relying on experience and intuition (McAfee \& Brynjolfsson, 2012). Empirical research confirms the advantages of data-driven decision making and has identified a positive association with firm performance (Brynjolfsson, Hitt, \& Kim, 2011). In summary, big data will trigger numerous changes in organizational decision making and design. It increases information visibility that enables data-driven decision making at both the strategic and operational levels (see Table 1).

Table 1. Comparison of Past and Future Information Visibility

\begin{tabular}{|l|l|l|}
\hline Characteristic & Smart Machine Era & Big Data Era \\
\hline Information Timeliness & Historical data & Real-time data \\
\hline Information Sources & Self-created, high-quality datasets & $\begin{array}{l}\text { Large amount of data including } \\
\text { unreliable external datasets }\end{array}$ \\
\hline Information Reach & Strategic level & Strategic and operational levels \\
\hline $\begin{array}{l}\text { Information Relevance for } \\
\text { Decision Making }\end{array}$ & $\begin{array}{l}\text { Low (experience-driven decision } \\
\text { making) }\end{array}$ & High (data-driven decision making) \\
\hline
\end{tabular}

\section{THE INFORMATION VISIBILITY PARADOX}

Information visibility has paradoxical characteristics. On the one hand, greater visibility “... serves as a means of empowering ... to make decisions which used to be formally referred upwards or to other departments" (Sia et al., 2002: 24). On the other hand, visibility offers new possibilities to keep subordinates as well as peers under surveillance and even to infringe on their personal privacy. Studies about this phenomenon are often based on the metaphor and theoretical lens of the information panopticon (Elmes, Strong, \& Volkoff, 2005; Sia \& Neo, 2008; Sia et al., 2002; Zuboff, 1988). The panopticon is a special design of an early nineteenth-century prison. An observation tower in the middle of a circular prison enables guards to view every cell. This creates "... a state of conscious and permanent visibility that assures the automatic function of power", where people behave as if they are under constant control (Foucault, 1979: 201). The psychological effects of such visibility are also evident in the context of information systems, where the knowledge that information is potentially visible for others likewise induces self-control (Zuboff, 1988).

The panopticon building creates hierarchical visibility for the guards, but the information 
panopticon in an organization offers horizontal visibility for peers and even subordinates. In the past, separate information-centric systems provided visibility mainly for management. In this regard, old information technologies increased bureaucracy by establishing more rationality and control along the organizational hierarchy (Weber, 1922). In contrast, horizontal visibility can empower workers and brings new opportunities for the creation of post-bureaucratic organizations (see Figure 1). Horizontal visibility is enabled by the blurring of information-centric and process-centric system boundaries as well as the accessibility of big data at the operational level. As Zammuto et al. (2007: 752) state, "[Integrated] enterprise systems decreased the need to move information through a hierarchy, allowing people to organize around the work itself... Everyone working on a particular process... could now use the process-based IT system to see and understand the whole work flow." In other words, empowerment requires that workers - and not only management - have an appropriate level of visibility.
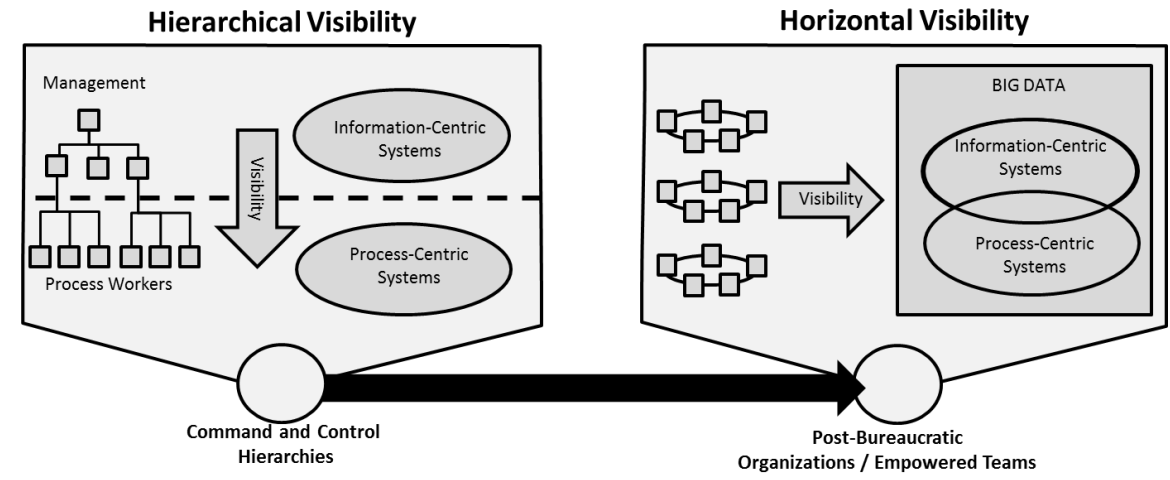

Fig. 1. Comparison of Hierarchical and Horizontal Visibility

Elmes, Strong, \& Volkoff (2005: 29) found that employees perceived “... visibility of information as empowering and took action based on this additional information." Psychological empowerment is defined as any increase in worker power that enables them to achieve organizational objectives (Seibert, Silver, \& Randolph, 2004). It is specified as an individual-level motivational state shaped by the work environment and manifested in a set of four cognitions: meaning, competence, self-determination, and impact (Spreitzer, 1995; Thomas \& Velthouse, 1990). Work context antecedents of psychological empowerment include access to information about unit performance and strategy (Spreitzer, 1995; Thomas \& Velthouse, 1990). Empirical research has found a strong positive relationship between employees' access to information and their feeling of psychological empowerment (Laschinger et al., 2004; Spreitzer, 1995). The existing literature also states that employees become more effective, innovative, and satisfied with increased levels of empowerment (Spreitzer, 1995; Spreitzer, Kizilos, \& Nason, 1997). This confirms earlier observations that information access rules are an IT-enabled constitution of power (Orlikowski \& Robey, 1991; Zuboff, 1988).

But information visibility not only empowers workers, it also controls them. Theoretically grounded in the information panopticon, Sia et al. (2002) call information systems that enable the surveillance of employees "panoptic control." Compared to enterprise resource planning (ERP) systems, which information panopticon research has studied so far (Elmes et al., 2005; Sia et al., 2002), big data technologies have higher tracking and information visibility capabilities.

Some empirical research has shown that information visibility can increase panoptic control and empowerment simultaneously (Elmes et al., 2005; Sia \& Neo, 2008; Sia et al., 2002). Thus, information visibility is a two-edged sword that enables employees to see and do more, while it makes them more visible to others at the same time (Elmes et al., 2005).

\section{LEVERAGING INFORMATION VISIBILITY}

Panoptic control does not necessarily have a negative impact on employees. Employees expect performance assessments based on information about their activities, but dysfunctions such as 
resistance or sabotage arise if surveillance goes beyond what is reasonable or necessary (Ball, 2010). Control dysfunctions are behaviors that are "inconsistent with the best interests of the organization", potentially resulting in lower job satisfaction and individual performance (Jaworski, 1988: 23). Therefore, it depends on the perceived adequacy of panoptic control whether it triggers dysfunctional behavior or intended self-control. Correspondingly, the growing big data literature recommends that organizations have to implement privacy protection rules and define data ownership in order to reap the benefits of big data (Lund et al., 2013). A case study underlines this: A company that implemented sophisticated real-time performance dashboards was not able to gain process improvements because its workforce showed a strong resistance to the measurement initiatives in fear of complete transparency of individual performance (Cleven, Winter, \& Wortmann, 2011). Increased transparency from new technologies requires adequate protection of private data from superiors and, since horizontal visibility is increasing, from co-workers. To realize benefits from the usage of big data, we propose that organizations consider the following:

Proposition 1: Control dysfunctions of big data usage are lower if privacy protection and data ownership rules are implemented.

Empirical studies confirm that psychological empowerment is significantly and positively related to individual performance and job satisfaction (Seibert et al., 2004; Spreitzer et al., 1997). However, the benefits of psychological empowerment are moderated by different factors. For example, the less structured the work context is, the higher the positive influence of psychological empowerment (Thomas \& Tymon, 1994). Also, the empowering effects of business process re-engineering are greater for knowledge-intensive processes than for standardized processes where the disciplinary effects of visibility are more dominant (Sia $\&$ Neo, 2008). Accordingly, we conclude the following for big data usage in organizations:

Proposition 2: The psychological empowerment benefits of big data usage are higher for knowledge-intensive processes than for standardized processes.

Information panopticon research identified that the empowering outcome of information systems implementation depends on "... clear management intentions to break away from pre-existing structures" (Sia et al., 2002: 35). An empowerment climate is positively related to individuals' perceived psychological empowerment and includes open information sharing, employee autonomy, and team accountability as key organizational practices (Seibert et al., 2004). Furthermore, Davenport \& Beers (1995: 74) conclude that “... giving line workers... information in real time without empowering them to act on it is, at best, wasteful, and, at worst, harmful." Thus, we propose:

Proposition 3: The psychological empowerment benefits of big data usage are higher for organizations with a strong empowerment climate.

An important dimension of psychological empowerment is the competence of employees (Spreitzer, 1995). Research indicates the need for training a large number of so-called data scientists in order to realize the potential of big data (Lund et al., 2013; Schroeck et al., 2012). Although we share the call for more data scientists, the switch from strategic to operational real-time use of big data calls for analytical skills development within existing operational roles as well as more decision competency. This leads to our final proposition:

Proposition 4: The psychological empowerment effects of big data usage are higher if analytical skills and decision competencies of operational employees are increased.

\section{CONCLUSION}

Our conceptual article links big data to information visibility, describes how visibility affects employee control and empowerment, and provides propositions that help organizations to exploit big data opportunities. Organizations can enhance information visibility in decision making by appropriate big data analytics. We use a panoptic lens to explore the control and empowerment paradox associated with big data in an organizational context. Horizontal information visibility - particularly for employees at the operational level - requires changes 
from hierarchical structures to post-bureaucratic structures, as less information moves through the hierarchy and workers can organize instead around the work itself. The propositions that we offer identify key variables in information processing and decision making, and they suggest research which could unlock the potential of big data in organizations.

\section{REFERENCES}

Ball K. 2010. Workplace surveillance: An overview. Labor History 51(1): 87-106.

Brynjolfsson E, Hitt LM, Kim HH. 2011. Strength in numbers: How does data-driven decision making affect firm performance? SSRN Electronic Journal. Accessed December 10, 2013: http://www.ssrn.com/abstract=1819486.

Chen H, Chiang RHL, Storey VC. 2012. Business intelligence and analytics: From big data to big impact. MIS Quarterly 36(4): 1165-1188.

Cleven A, Winter R, Wortmann F. 2011. Process performance management: Illuminating design issues through a systematic problem analysis. Proceedings of the 2011 ACM Symposium on Applied Computing: 280-286.

Davenport TH, Beers MC. 1995. Managing information about processes. Journal of Management Information Systems 12(1): 57-80.

Elmes MB., Strong DM, Volkoff O. 2005. Panoptic empowerment and reflective conformity in enterprise systems-enabled organizations. Information and Organization 15(1): 1-37.

Forrester Research. 2010. Forrester TechRadar: Enterprise data integration. Accessed December 10, 2013: http://www.forrester.com/Forrester+TechRadar+Enterprise+Data+In tegration+Q1+2010/fulltext/-/E-RES56028.

Foucault M. 1979. Discipline and Punish: The Birth of the Prison. Peregrine Books, London, U.K.

Galbraith JR. 2012. The future of organization design. Journal of Organization Design 1(1): 3-6.

Gantz BJ, Reinsel D. 2011. Extracting value from chaos state of the universe. Accessed December 10, 2013: http://www.emc.com/collateral/analyst-reports/idc-extracting-valuefrom-chaos-ar.pdf.

Jaworski BJ. 1988. Toward a theory of marketing control: Environmental context, control types, and consequences. Journal of Marketing 52(3): 23-39.

Laney D, LeHong H, Lapkin A. 2013. What big data means for business. Financial Times. Accessed December 10, 2013: http://www.ft.com/intl/cms/s/0/b1dec7f4-b686-11e2-93ba00144feabdc0.html\#axzz2gBZKTk4m.

Laschinger HKS, Finegan JE, Shamian J, Wilk P. 2004. A longitudinal analysis of the impact of workplace empowerment on work satisfaction. Journal of Organizational Behavior 25: 527-545.

Lock M. 2010. Operational intelligence: Boosting performance with "right-time" business insight. Accessed December 10, 2013: http://www.aberdeen.com/aberdeen-library/6528/ RA-operational-business-intelligence.aspx.

Loos P, Lechtenbörger J, Vossen G, Zeier A, Krüger J, Müller J, Lehner W, Kossmann D, Fabian B, Günther O, Winter R. 2011. In-memory databases in business information systems. Business \& Information Systems Engineering 3(6): 389-395.

Lund S, Manyika J, Nyquist S, Mendonca L, Ramaswamy S. 2013. Game Changers: Five Opportunities for US Growth and Renewal. McKinsey Global Institute, San Francisco, CA.

Manyika J, Chui M, Brown B, Bughin J, Dobbs R, Roxburgh C, Byers HA. 2011. Big Data: The Next Frontier for Innovation, Competition, and Productivity. McKinsey Global Institute, San Francisco, CA.

McAfee A, Brynjolfsson E. 2012. Big data: The management revolution. Harvard Business Review October 2012: 1-9.

Orlikowski WJ, Robey D. 1991. Information technology and the structuring of organizations. Information Systems Research 2(2): 143-169.

Schroeck M, Shockley R, Smart J, Romero-Morales D, Tufano P. 2012. Analytics: The realworld use of big data. Accessed December 10, 2013: http://www-935.ibm.com/services/ 
us/gbs/thoughtleadership/ibv-big-data-at-work.html.

Seibert S, Silver S, Randolph W. 2004. Taking empowerment to the next level: A multiplelevel model of empowerment, performance, and satisfaction. Academy of Management Journal 47(3): 332-349.

Sia SK, Neo BS. 2008. Business process reengineering, empowerment and work monitoring: An empirical analysis through the panopticon. Business Process Management Journal 14(5): 609-628.

Sia SK, Tang M, Soh C, Boh WF. 2002. Enterprise resource planning (ERP) systems as a technology of power: Empowerment or panoptic control? The DATA BASE for Advances in Information Systems 33(1): 23-37.

Spreitzer GM. 1995. Psychological empowerment in the workplace: Dimensions, measurement and validation. Academy of Management Journal 38(5): 1442-1465.

Spreitzer GM, Kizilos MA, Nason SW. 1997. A dimensional analysis of the relationship between psychological empowerment and effectiveness, satisfaction, and strain. Journal of Management 23(5): 679-704.

Thomas K, Tymon W. 1994. Does empowerment always work: Understanding the role of intrinsic motivation and personal interpretation. Journal of Management Systems 6(3): $1-13$.

Thomas K, Velthouse B. 1990. Cognitive elements of empowerment: An "interpretive" model of intrinsic task motivation. Academy of Management Review 15(4): 666-681.

Weber M. 1922. Wirtschaft und Gesellschaft - Grundriß der Verstehenden Soziologie. Mohr, Tübingen, Germany.

Zammuto RF, Griffith TL, Majchrzak A, Dougherty DJ, Faraj S. 2007. Information technology and the changing fabric of organization. Organization Science 18(5): 749-762.

Zuboff S. 1988. In the Age of the Smart Machine: The Future of Work and Power. Basic Books, New York, NY.

\section{MARTIN BERNER}

Institute for Enterprise Systems

University of Mannheim

E-mail: berner@es.uni-mannheim.de

\section{ENRICO GRAUPNER}

Institute for Enterprise Systems

University of Mannheim

E-mail: graupner@es.uni-mannheim.de

\section{ALEXANDER MAEDCHE}

Institute for Enterprise Systems

University of Mannheim

E-mail: maedche@es.uni-mannheim.de 